\title{
«O rio comanda a vida»: Aprendizagem do nado em uma comunidade ribeirinha do Amazonas
}

\author{
Rônisson de Souza de Oliveira, Mg. \\ Instituto de Desenvolvimento Sustentável Mamirauá, Brasil* \\ Nelissa Peralta, Ph.D \\ Universidade Federal do Pará, Brasil **
}

\section{Resumo (analítico)}

O objetivo deste artigo é descrever os processos e significados envolvidos na aprendizagem do nado entre crianças ribeirinhas do médio rio Solimões. A pesquisa questiona os métodos de aprendizagem e o que aprender a nadar representa em termos de construção da pessoa. Assim, recorremos a um estudo exploratório, com abordagem qualitativa e estudo de caso. Realizamos registros fotográficos, entrevistas semiestruturadas e observação participante. As crianças aprendem a nadar por meio de brincadeiras, em espaços específicos nas beiras dos rios, no período de inundação. Aprender a nadar lhes permite circular de forma autônoma nos espaços comunitários e lhes torna aptos a participar também do mundo da pesca. Concluímos que a natação é fundamental para a formação da pessoa, construção e afirmação da territorialidade do grupo.

\section{Palavras-chave}

Infância, aprendizagem, nado, rio, Amazônia.

\section{Thesauro}

Tesauro de Ciencias Sociales de la Unesco.

\section{Para citar este artículo}

Oliveira, R. de S., \& Peralta, N. (2020). «O rio comanda a vida»: Aprendizagem do nado em uma comunidade ribeirinha do Amazonas. Revista Latinoamericana de Ciencias Sociales, Niñez y Juventud, 18(1), 1-27. http://dx.doi.org/ $10.11600 / 1692715 \times .18104$

\section{Historial}

Recibido: 23.04.2019

Aceptado: 23.07.2019

Publicado: 20.11.2019

\section{Información artículo}

Artigo de investigação científica e tecnológica, desenvolvido a partir do projeto denominado «Produção e reprodução das técnicas e saberes tradicionais na pesca no Setor Coraci, RDSA», desenvolvido entre outubro de 2015 e ja neiro de 2019 com bolsa do Conselho Nacional de Desenvolvimento Científico e Tecnológico (CNPq), no Programa de Capacitação Institucional (PCI) do Instituto de Desenvolvimento Sustentável Mamirauá (IDSM). A investigação que deu origem a esse artigo foi realizada entre fevereiro e junho de 2017. O projeto foi aprovado no comitê de ética do IDSM, com o parecer de número 2544 573. Área: sociologia; subárea: sociologia e antropologia. 


\section{«The river commands life»: Learning how to swim in a riverside village in the Amazon}

Abstract (analytical)

The authors describe the processes and meanings involved in learning how to swim among children who live next to the river in the Middle Amazon River region. The research investigates swimming techniques and what they mean for the construction of a person. The authors carried out an exploratory study with a qualitative approach and a case study design. Semi-structured interviews and participant observation techniques were used. Results show that children learn to swim through games in specific spaces near the river, especially during the rainy season. Developing their swimming techniques allows them to circulate autonomously in the community, develop their strength and participate in the world of fishing. The authors conclude that swimming is a skill that has very high relevance for children who live along the river and is fundamental for the formation of a person and the construction and affirmation of the territoriality of the group.

Keywords

Childhood, learning, swimming, river, Amazonia.

\section{«El río manda la vida»: aprender a nadar en una comunidad ribereña en el Amazonas}

\section{Resumen (analítico)}

Este artículo tiene como objetivo describir los procesos y significados involucrados en el aprendizaje del nado entre los niños ribereños del medio río Amazonas. La pregunta de investigación cuestiona las modalidades de aprendizaje de natación y qué significa para la construcción de la persona. Para responderla, recurrimos a un estudio de tipo exploratorio, con enfoque cualitativo y diseño de estudio de caso. Aplicamos la entrevista semiestructurada y la observación participante. Los niños aprenden a nadar por medio de juegos, especialmente en el período de inundación. Desarrollar las técnicas de natación les permite circular de forma autónoma en la comunidad y los vuelve aptos a participar también del mundo de la pesca. Concluimos que nadar es fundamental para la formación de la persona, así como la construcción y afirmación de la territorialidad del grupo.

Palabras clave

Infancia, aprendizaje, natación, río, Amazonia.

Información autores

[^] Graduado em História pela Universidade do Estado do Amazonas. Mestre em Sociologia pela Universidade Federal do Amazonas. Doutorando em Ciências Sociais pela Universidade Estadual de Campinas e pesquisador vinculado ao grupo de Pesquisas Sociais do Instituto de Desenvolvimento Sustentável Mamirauá.

(iD) 0000-0001-8743-0449. H5: 1. Correio eletrônico: ronisson57@hotmail.com

[**] Doutora em Sociologia pela Universidade Federal de Minas Gerais. Professora Adjunta na Faculdade de Ciências Sociais da UFPA. ID 0000-0002-1976-7389. H5: 6. Correio eletrônico: nelissapb@ufpa.br 


\section{Introdução}

«O rio comanda a vida» é uma frase que intitula o livro do escritor paraense Leandro Tocantins (1973). Na Amazônia, o rio comanda a vida e, por vezes, também a morte. Nadar é um ato repleto de significados que envolve técnicas corporais que as crianças desenvolvem por meio da aprendizagem prática no dia a dia.

As águas que correm os rios têm significados diversos para as pessoas na Amazônia: fonte de movimento, de produção, de medo. Na literatura sobre a região é raro que as águas passem despercebidas, especialmente por conta da grande influência da sazonalidade dos seus ciclos no modo de vida das populações que vivem às margens dos rios. «O rio e seu ciclo de águas são incorporados como dimensão fundamental na vida das comunidades ribeirinhas» (Azevedo \& Castro, 2009 apud Loureiro, 2015, p. 192). Para Loureiro (2015) são «poucas regiões do mundo guardam uma relação com seus rios e uma dependência tão grande deles como a Amazônia» (p. 269). Antônio Carlos Witkoski (2010), ao denominar as águas do Amazonas, como águas de trabalho ressalta que «o tempo ecológico, comandado pelos ciclos das águas, aparece como força imperativa» (p. 33 ) no modo de vida das populações amazônicas. Para Andrade e Pacheco (2016, p. 106) «o tempo amazônico é o do movimento das águas». Sobre a região onde realizamos esta pesquisa, Reis (2005) afirma que:

o rio constitui, praticamente, a única via de comunicação e transporte dos ribeirinhos. É o meio que liga as comunidades entre si, com as sedes dos municípios e com os centros urbanos. É através dos cursos d'água mais importantes que a população se abastece de água, escoa seus produtos, estabelece e mantém relações sociais com as vizinhanças. (p. 43)

O modo de vida ribeirinho é constituído, portanto, a partir dos movimentos das águas e do envolvimento com os rios. Como afirma Lima (2004, p. 59) o «termo ribeirinho designa qualquer população que vive às margens dos rios», mas também é uma categoria política (Lima, 2004; Neves, 2006) disseminada a partir das intervenções da Igreja católi- 
ca nos anos 1970 para fortalecer essas populações na sua luta e em defesa de seus territórios. Em termos de meios de vida:

os ribeirinhos são policultores familiares (agricultores, principalmente, mas também, complementarmente, pescadores e extratores de recursos da floresta), que, operando em ambiente de várzea, áreas situadas nas margens de rio, sujeitas a inundações periódicas (de maior ou menor intensidade), gerem disposições específicas. (Neves, 20o6, p. 4)

Em comunidades ribeirinhas as crianças circulam em muitos espaços, porém com certas restrições. Na primeira infância, há sempre alguém atento para reprimir qualquer ato que lhes ponha em perigo ou que seja inadequado aos olhos dos adultos. Como observado por Medaets (2013), «apesar de não terem permissão dos pais para exercer uma mobilidade total nesse território, as crianças podem, no entanto, frequentar um número razoável de casas e lugares». No contexto de território indígena Silva (2013) observa que «é na casa e no quintal que vamos observar o gradativo processo de participação da criança na vida e atividades do seu grupo doméstico e suas primeiras saídas em direção às casas dos outros parentes e de outros espaços de construção da pessoa Xakriabá» (p. 40). Esse é o espaço inicial em que a criança começa a se constituir enquanto pertencente àquela aldeia. Complementando a ideia do autor podemos considerar que também iniciam ali processos de aprendizagem de habilidades.

As crianças e seus processos de aprendizagem já foram questões marginais nas Ciências Sociais. Embora as crianças não tenham sido totalmente invisibilizadas, pois estão em todos os processos sociais, a elas não foi dada prioridade como sujeitos de pesquisa. $\mathrm{Na}$ sociologia «historicamente, as crianças ocuparam um lugar secundário» (Cunha, 2013, p. 84). Na antropologia, entretanto, «o espaço para as discussões sobre as crianças e as infâncias têm se ampliado e consolidado» (Cohn, 2013, p. 222).

O olhar para as crianças amazônicas na sua relação com os rios está presente em alguns trabalhos. Sautchuk $(2007,2015)$ aborda a aprendizagem da pesca entre crianças do sexo masculino, na Vila do Sucuriju (AP) destacando os processos de iniciação dos meninos como pescadores do lago ou do mar. Morelli (2017) aborda a relação das crianças Matses com os rios como espaço de socialização, onde passam a maior parte do tempo brincando e desenvolvendo habilidades que são chave para a sua sobrevivência. O trabalho de Medaets (2013) trata das práticas e normas educativas entre comunidades ribeirinhas da região do Tapajós. Não encontramos, entretanto, na literatura pesquisas sobre a aprendiza- 
gem da técnica do nado. Desse modo, buscamos mostrar esse aspecto da prática social do modo de vida ribeirinho, considerando esta como prática central na vida das pessoas.

Como ponto inicial é fundamental esclarecer que na Amazônia a prática de nadar e seus significados são diferentes para comunidades ribeirinhas e centros urbanos. $\mathrm{Na}$ Amazônia, mesmo nas cidades, as pessoas conhecem e circulam nos rios, paranás e igarapés; as águas estão sempre próximas, porém os estímulos para aprender a nadar são diferentes. Na cidade aprender a nadar está mais ligado ao lazer e ao transporte. Nas comunidades ribeirinhas, apesar de também fazer parte das atividades de lazer, o nado está associado aos meios de vida. Essa comparação, apesar de aparentemente ser trivial, tem relevância, pois nas comunidades ribeirinhas as crianças, desde muito cedo, estão imersas nas águas. Nadar envolve corpo, ambiente, interação entre gerações, é uma prática integrada ao modo de vida das populações ribeirinhas. Os significados da aprendizagem do nado serão descritos nesse trabalho à luz da antropologia da técnica e da aprendizagem com objetivo de contextualizar processos de aprendizagem do nado entre as crianças da comunidade estudada.

Este trabalho faz parte de uma pesquisa etnográfica sobre os saberes e as práticas tradicionais de pescadores na região Amazônica do médio rio Solimões, como já ressaltado. A intenção da pesquisa «guarda chuva» era entender como os sujeitos produzem e reproduzem seus saberes e práticas na pesca. Como nos mostra a etnografia do antropólogo Carlos Sauthuck (2015), existe uma estreita relação entre o desenvolvimento de habilidades técnicas de pesca e a construção da pessoa do pescador. Portanto, conhecer o processo de aprendizagem da técnica, também significa conhecer o processo de formação do pescador como sujeito, que o torna apto e disposto a ser e agir como pescador no ambiente. Isso, por sua vez, lhe permite participar do «esforço coletivo do grupo social para ocupar, usar, controlar e se identificar com uma parcela de seu ambiente biofísico» (Little, 2004), ou seja, de construir sua territorialidade.

Os dados de campo junto aos pescadores e as etnografias da aprendizagem na pesca (Sauthuck, 2015) nos sugeriram que o processo de aprendizagem ocorre entre os meninos e meninas em tenra idade, entre 5 e 6 anos, a partir das oportunidades que parentes consanguíneos oferecem às crianças de acompanhá-los na pesca. Entretanto, nem todas as crianças dispunham dessas oportunidades de aprendizagem na pesca, bem como de 
«liberdade»1 para estarem sozinhas em outros espaços, que, em última instância, possibilitam a construção da pessoa e sua participação na territorialidade do grupo. Assim, nos indagamos sobre os processos anteriores à inserção das crianças no mundo da pesca. E, por isso, voltamos nossa atenção para a primeira infância ribeirinha. De que práticas participavam essas crianças? Quais eram suas brincadeiras? Como se dava o processo de formação da criança ribeirinha? Na época da pesquisa, as respostas estavam sempre relacionadas com as águas, a beira e o envolvimento das crianças com o rio. Nadar mostrouse como um importante elemento da formação da pessoa naquele contexto e uma das principais habilidades nos percursos de aprendizagem das crianças ribeirinhas. Assim, nos propusemos a responder a seguinte questão: quais são os processos e os significados envolvidos na aprendizagem do nado entre crianças ribeirinhas da região rural da Amazônia? Para respondê-la, recorremos a um estudo do tipo exploratório, com abordagem qualitativa e desenho de estudo de caso (de uma comunidade). A tese que apresentamos é que aprender a nadar faz parte de um repertório que possibilita o acesso aos demais ambientes de aprendizagem do modo de vida ribeirinho. Assim como Silva e Gomes (2015) tentamos explorar a aprendizagem do nado estabelecendo interrelações entre as configurações de diferentes aprendizagens. Na coleta de dados foi privilegiada a técnica de observação participante, com a materialidade de caderno de campo e registros fotográficos. A investigação foi norteada pelo arcabouço teórico das noções de aprendizagem situada e comunidade de práticas (Lave \& Wenger, 1991).

\section{Metodologia}

\section{Área de estudo: São Paulo do Coraci}

A proposta desse trabalho foi realizar uma descrição sobre como as crianças aprendem a nadar em uma comunidade ribeirinha do Amazonas usando como métodos de pesquisa a observação, entrevistas semiestruturadas e registros fotográficos. As interações que geraram as observações sobre esse aspecto de aprendizagem, ocorreram dentro do trabalho de campo de uma pesquisa de maior escopo desenvolvida na região sobre produção e reprodução de técnicas e conhecimentos tradicionais na pesca, e que teve duração de quatro anos (2015-2019). É importante destacar também que um dos autores

\footnotetext{
${ }^{1} \mathrm{O}$ sentido de liberdade que falamos, a partir das observações significa que as crianças obedecem as regras estabelecidas localmente, mas tem certa liberdade e mobilidade em alguns dos espaços que envolvem água, uma liberdade que não teriam antes.
} 
(R. Oliveira) passou parte da infância até os 12 anos nessa comunidade, passando por esse processo de aprendizagem.

Os dados foram gerados, a partir das premissas metodológicas da antropologia, com a observação participante nos espaços sociais onde circulam as crianças, adolescentes, jovens e adultos nos mais diferentes momentos que envolviam as águas e as interações que geram a aprendizagem do nado. A observação das técnicas do nado foi realizada durante zo dias na comunidade ribeirinha São Paulo do Coraci em maio de 2017 (período máximo do nível das águas, quando o contato das pessoas de todas as gerações com as águas é mais frequente).

A comunidade de São Paulo está situada no município de Maraã, (AM), na margem esquerda do paraná do Coraci, em uma área de várzea, alagada sazonalmente. O território está situado na Reserva de Desenvolvimento Sustentável Amanã (RDSA), unidade de conservação criada em 1998.A RDS Amanã tem área total de 2313 ooo hectares, abrangendo território dos municípios de Maraã, Coari, Barcelos e Codajás. Uma parte significativa da reserva é formada por ambiente de terra firme, outra parte por ambiente de várzea» (Alencar, 2010 p. 46) e igapó (Lima \& Peralta, 2016). Terra firme são áreas de floresta localizadas em terras altas, que correm pouco risco de inundação, com elevada biomassa e alta biodiversidade (Ayres, 2006). Várzea são áreas alagáveis com o processo da sazonalidade, seus solos «são constantemente renovados, pois ficam submersos nas águas brancas por quase metade do ano» (Ayres, 2006, p. 16), enquanto os «igapós são florestas inundáveis, localizadas ao longo dos rios de águas claras e de águas pretas» (Ayres, 2006, p. 14).

O lugar onde se encontra a comunidade tem uma estimativa de ocupação histórica datada de 1930 (Cunha, 2000; Alencar, 2007), porém a sua organização política enquanto comunidade ocorre da intervenção da Igreja Católica, nos anos de 1980 (Alencar, 2007). As famílias que moravam dispersas por diferentes lugares, no curso do rio Coraci, agruparam-se, formando assim as denominadas comunidades: «o termo comunidade foi introduzido nessa região amazônica [do médio Solimões] pela Igreja católica nos anos 1970 através de ações do MEB» (Alencar, 2009, p. 188). A reunião das famílias antes dispersas não era aleatória, mas organizada por relações de parentesco e compadrio.

${ }_{2}^{2}$ Unidade de Conservação criada pelo governo do Estado do Amazonas através do Decreto 19 021/98. 
O paraná do Coraci é uma ramificação do rio Japurá, onde estão localizadas diversas comunidades, porém no setor ${ }^{3}$ político do Coraci se concentram atualmente apenas as comunidades de Nova Macedônia, São Paulo do Coraci, Nova Canaã, Matuzalém e São João do Ipecaçu. ${ }^{4}$ Essas comunidades estão em áreas de várzeas e de terra firme e suas atividades econômicas principais são a pesca, a agricultura e o artesanato (Sousa, 2017). A comunidade São Paulo é formada atualmente por 10 famílias, com população de 49 habitantes, desse total: 22 são mulheres e 27 homens, em uma distribuição de 17 adultos, 17 adolescentes e jovens e 15 crianças.

É importante destacar que a comunidade São Paulo se localiza em ambiente de várzea, alagada sazonalmente, geralmente de maio a julho, com períodos de seca entre os meses de setembro, outubro e novembro (Ramalho et al., 2009). A sazonalidade das águas oferece condições para o desenvolvimento das técnicas produtivas agrícolas, de pesca e extrativismo nesse ambiente. A sazonalidade também tem influência na interação das crianças com os espaços aquáticos. No período da seca, as crianças que não sabem nadar geralmente não se aproximam sozinhas das margens do rio, ou são monitoradas constantemente para não entrarem na água, quando estão no espaço denominado como «beira». 5 Nessa época o rio tem correnteza forte, o que oferece perigo às crianças que não sabem nadar. Já no período de cheia, as configurações do espaço se modificam, a proximidade da água favorece a maior interação de todos os moradores (incluindo as crianças) com as águas que ao invadirem os barrancos, formam pequenas bacias, sem muita profundidade e com menor correnteza.

3 No mesmo paraná (braço do rio) também se encontra o setor São José.

4 A comunidade Ebenezer se encontra geograficamente no setor, porém não participa da organização política.

5 Estar na beira é ficar nas balsas que ficam na margem do rio, onde são ancoradas as canoas e onde ocorre lavagem de roupas, vasilhas e onde as pessoas tomam banho. 
Figura 1

Crianças no barranco da comunidade São Paulo, na margem do rio Coraci

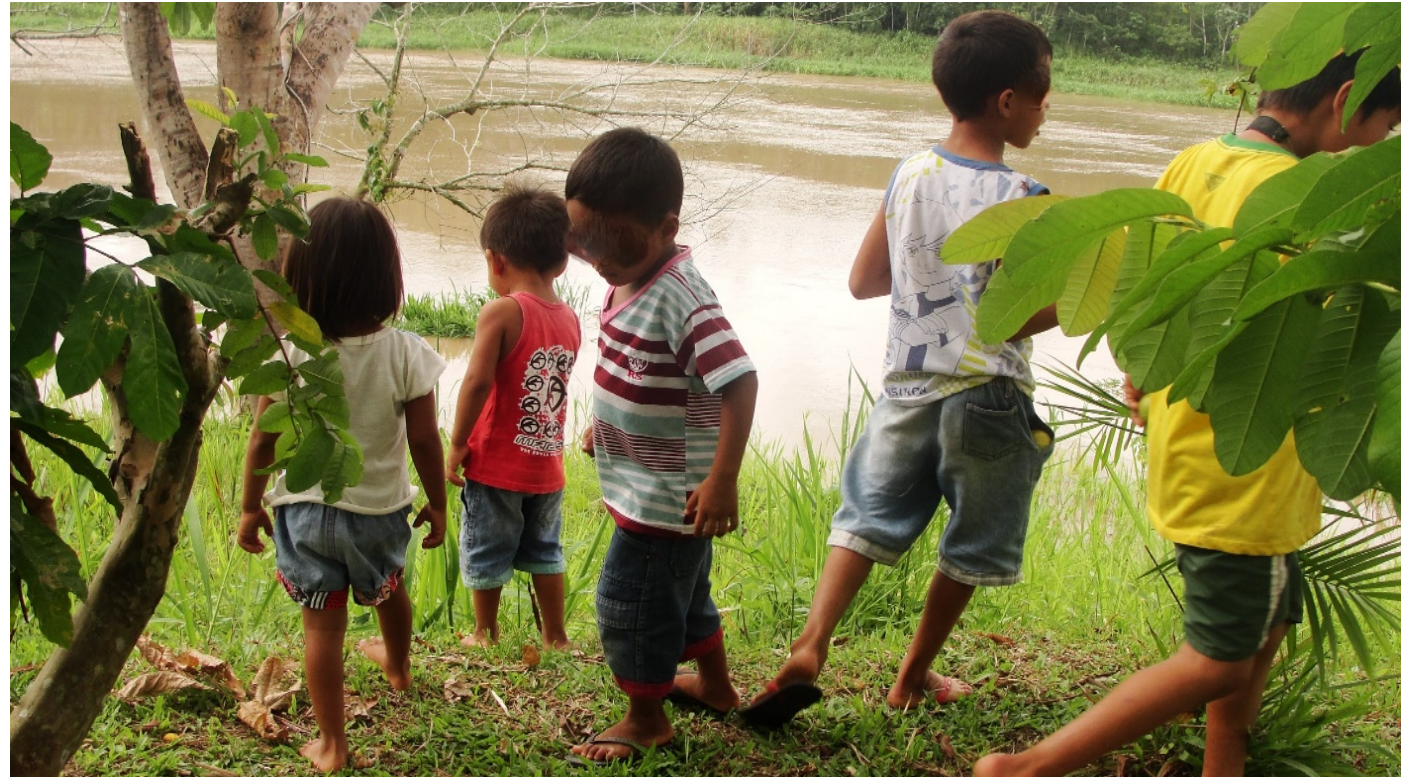

Nota. (2) 2019 R. Oliveira.

A imagem mostra as crianças na interação com a paisagem da comunidade: em grupos elas brincam, brigam, correm, sobem nas árvores, apanham e comem frutos, exploram diversos espaços da comunidade, tudo ao ritmo de diversas brincadeiras com bolas, brincadeiras de correr, de esconder, comuns de crianças ribeirinhas. No entanto, como propõe Medaets (2013), os pais impõem limites nem sempre perceptíveis a quem passa pouco tempo no lugar, limites estes associados não apenas à redução de riscos, mas à hierarquia intergeracional e aos papeis das crianças no cotidiano das famílias —os pais solicitam ajuda das crianças para que façam certas atividades como levar e buscar recados, objetos e alimentos aos vizinhos, ou acompanhá-los na roça, na casa de farinha, etc.

\section{Resultados}

As atividades desenvolvidas na comunidade são dinâmicas e constantemente há interações entre todos. No entanto, a divisão social do trabalho é demarcada quanto ao gênero. Um exemplo é o trabalho doméstico, considerado «trabalho de mulher», somente em raríssimas vezes homens lavam roupas, louças ou fazem comida, geralmente quando nenhuma mulher se encontra no espaço doméstico. Reis (2005) tratando do contexto 
da região do médio Solimões (reserva Mamriauá) ressalta que «a extração de madeira e a pesca são consideradas tarefas mais predominantemente masculinas. As mulheres têm papel importante na maioria das atividades, na agricultura, no processamento e distribuição dos alimentos e no cuidado com os filhos» (p. 41). Seguramente essa divisão não se dá da mesma forma para todas as famílias ao longo do tempo. Embora seja o modelo mais recorrente, temos clareza que podem existir variações de trabalho entre os gêneros. Porém, essa divisão foi também observada na comunidade pesquisada.

Nas atividades de lazer interagem gêneros e gerações, nas rodas de conversas e jogo de futebol nos finais de tarde e após o cultó religioso aos domingos de manhã (praticam a religião católica). Adolescentes, jovens, crianças e alguns adultos jogam futebol juntos, porém nas competições maiores, realizadas aos domingos entre diferentes comunidades, homens e mulheres não competem juntos. Outra atividade bastante desenvolvida nas horas de lazer é «pular n'água»: expressa em convites frequentes de «vamos pular n'água?!» Expressão comum, especialmente no período de cheia, quando as águas estão próximas.

A conexão com o rio faz parte da vida, pois o contato com as águas está incluído em todas as formas de mobilidade e produção. Porém, com as águas também há um cuidado constante, pois ela é «fonte de morte», como será explicado mais a frente, mesmo assim a interação é constante e necessária.

As águas são espaços sociais que constituem o território dos ribeirinhos. $\mathrm{O}$ acesso às águas é crucial para que as experiências corpóreas das crianças permitam a fabricação da pessoa nesse território de águas. O envolvimento das crianças com o mundo do trabalho, seja na pesca, na agricultura ou outra atividade, se dá pelo acompanhamento das atividades dos pais ou dos avós. Como destaca Reis (2005, p. 41) «as crianças acompanham todas as atividades econômicas familiares desde pequenas». É uma dinâmica de inserção e aprendizagem entre as gerações e no ambiente.

Por frequentarem quase todos os espaços dos adultos, o encontro das crianças com as águas é frequente, seja para se locomover entre comunidades, acompanhando as mães na lavagem de roupas e vasilhas, ou mesmo em atividades de lazer na companhia de adolescentes e jovens. $\mathrm{O}$ encontro direto com as águas acontece com mais frequência durante o período da cheia, quando as águas «invadem» os espaços terrestres das comunidades, casas e quintais.

6 Os moradores desse local denominam tal cerimônia religiosa, do domingo, de culto ou celebração, só denominam de missa quando o padre realiza a cerimônia. 
À medida que vão crescendo, sua circulação fora do espaço doméstico da casa e do quintal começa a ser permitida. Mas, saber nadar é um requisito essencial para a criança ter a autonomia para circular por diferentes espaços de forma mais independente. Assim, a aprendizagem do nado é um fato importante na vida das crianças. Aprender a nadar amplia a autonomia infantil e a interação com as crianças de outros grupos domésticos.

Jovens, adolescentes e crianças são os que mais «pulam n'água», estão sempre com tempo para isso e o fazem em um lugar específico, no período da cheia. Toda família tem uma pequena balsa, estrutura de madeira que fica dentro do rio, ligada por uma prancha de madeira ao espaço em frente à casa da família. É nesse local onde são desenvolvidas as atividades de banho e lavagem de roupas e vasilhas. Tomar banho em balsa não é o mesmo que «pular n'água», pois o banho é realizado de forma mais estática: a pessoa, ainda vestida, fica sentada ou em pé e tem o auxílio de um recipiente (vasilha ou cuia) para jogar água no corpo com a finalidade de lavar-se.

Pular n'água é uma atividade mais lúdica, dinâmica, integrada às brincadeiras, como brincar de «pira» e de «briga de galo». A pira (conhecida em outras regiões como pegapega) consiste em uma brincadeira de grupo, apenas uma pessoa é escolhida para ficar com a pira e esta deve tentar tocar em outra pessoa, para passar a pira adiante. Quando a pira acontece na água é uma brincadeira praticada somente por quem sabe nadar, porque exige que a criança ou adolescente seja sagas, ou seja, sagaz para se movimentar dentro da água e escapar de quem está com a pira. A briga de galo é praticada, sempre na água, por quatro pessoas, duas pessoas carregam nos ombros outra pessoa, as pessoas carregadas travam um duelo de empurrões tentando derrubar uma a outra, vence quem conseguir derrubar o adversário. É praticada em lugares de pouca profundidade, pois as pessoas responsáveis por carregar precisam ficar firmes, com os pés na terra.

O espaço físico, onde se «pula n'água» fica na parte de baixo da comunidade São Paulo. Lá jovens e crianças se encontram e ficam durante determinado tempo, até que se cansem ou que os pais os chamem para suas casas. Apesar de não haver horário estabelecido para pular na água, nos dias de semana isso ocorre mais durante as horas do almoço, das 11 h até 12 ḩ3o em média e nos finais de tarde após as 17h, isso devido aos horários de aula na comunidade. Já nos finais de semana não existe horário definido, a todo o momento do dia podem se formar grupos para pular na água, no espaço já determinado. 
Esse espaço não é escolhido por acaso, é um pequeno igarapé7 (pequeno curso d'água) que corta a comunidade e tem partes altas e baixas, assim interagem crianças, que sabem nadar, (mas que têm pouca resistência e precisam alcançar a terra rapidamente), com as crianças mais velhas (que têm mais resistência e podem ficar e nadar em lugares mais fundos), além de crianças que não sabem nadar, e que ficam sob o olhar atento de adultos que estão próximos.

Pode-se considerar que esse é um espaço de aprendizagem do nado, onde, de forma indireta e por meio de brincadeiras, as crianças são iniciadas nas técnicas corporais do nado e mergulho, que são fundamentais para viver naquele ambiente. A seguir a imagem do espaço utilizado para pular n'água.

\section{Figura 2}

\section{Crianças e adolescentes pulando n'água, no local preferido para essa atividade}

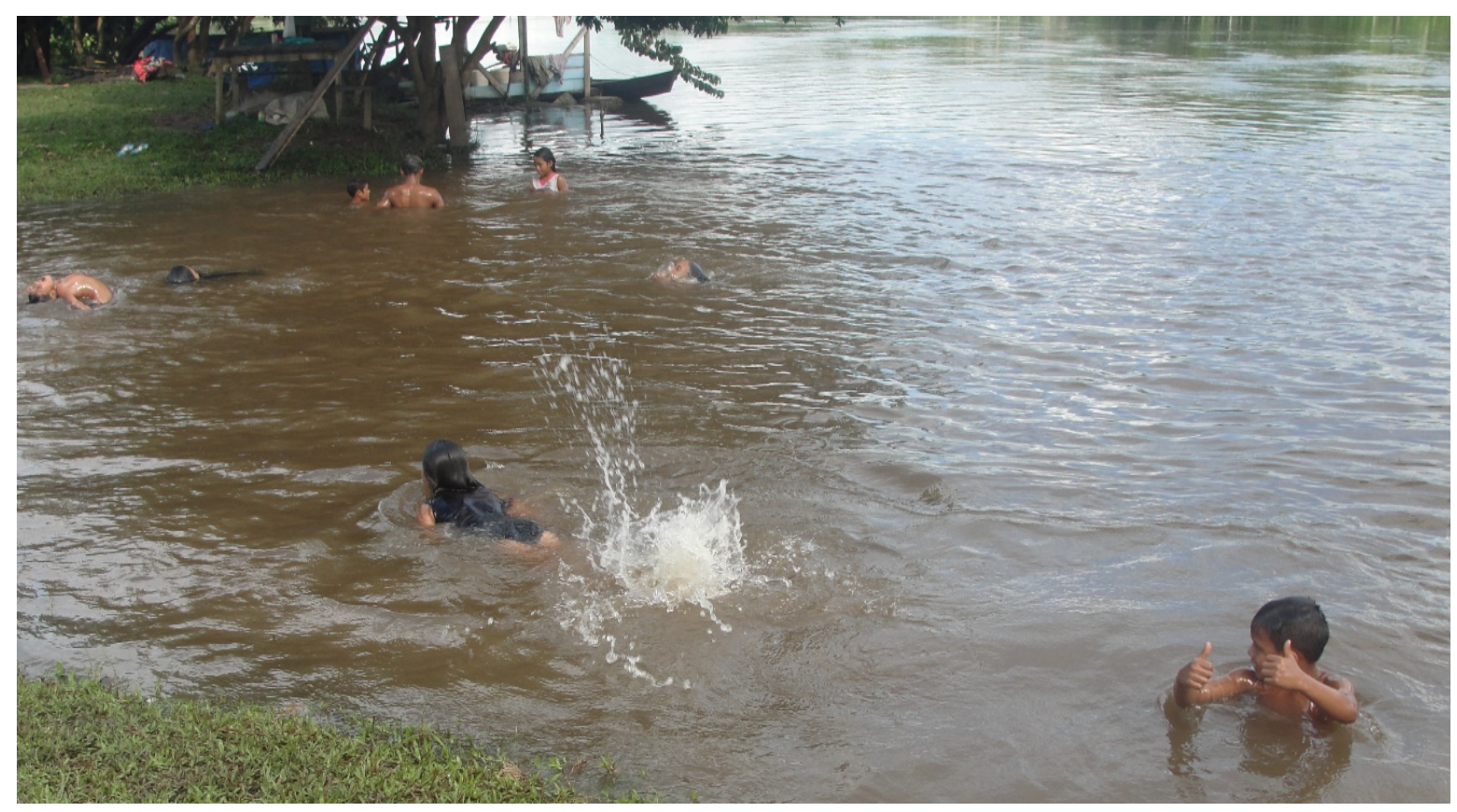

Nota. (C) 2019 R. Oliveira.

A imagem demonstra o lugar específico onde há a interação das crianças e jovens com as águas, não há uma sincronia de brincadeiras, cada um se diverte ao seu modo. Meninas e meninos que sabem nadar se jogam nas águas, com a liberdade de fazer o que

7 Os moradores designam a posse desses espaços, conforme a sua localização. Desse modo, o igarapé «pertence» a quem mora próximo dele, e se referem destacando igaparé do/a fulano/a. 
quiserem. Assim, nadam de diferentes formas, treinam as habilidades corporais, mergulham, conversam, brincam de pira e assim utilizam para a diversão esse espaço.

\section{Viagem a campo pelo fluxo das águas e as percepções sobre o nado}

As viagens de Tefés para a comunidade duram no mínimo dez horas, em embarcações com motores de popa de baixa potência, denominados «rabetas» ou em motores de maior potência, com barcos pequenos. No barco as crianças são as que mais circulam, em meio a produtos alimentícios, caixas de gelo, redes e pessoas. Estão sempre em movimento gastando as energias próprias da idade ou fazendo pequenas tarefas para os mais velhos. Elas têm técnicas corporais e habilidades para andar pela beira do barco sem cair na água, porém as crianças que andam pela borda são as que já sabem nadar, com as que não sabem, há cuidado especial —há sempre um adulto por perto, segurando para que não se desequilibre e caia na água.

Das 15 crianças moradoras da comunidade, somente sete não sabem nadar, porém essas crianças têm idades entre dois e seis anos e as demais são bebês com apenas meses de vida. O caso da criança de seis anos é o mais incomum, pois com cinco anos as crianças já sabem nadar ou já estão bem avançadas na aprendizagem. Neste caso quando perguntamos sobre o motivo da não aprendizagem, justificou-se que a criança estava ausente da comunidade no período de cheia intensa do rio no ano de 2017. Fato que nos indicou que é esse o período, quando as crianças de idade apropriada devem entrar em contato direto com as águas e aprender a nadar.

Na comunidade de São Paulo as águas estão no quintal, ou melhor, as águas são o quintal no período das cheias, ambientes propícios para estimular o desenvolvimento das primeiras habilidades no nado. Nesse período do ano há certo estímulo dos pais para que as crianças aprendam a nadar, porque água muito próxima às casas representa mais perigo: as crianças que não sabem nadar podem cair no rio e morrerem afogadas, como expressa uma das nossas interlocutoras ao ser questionada do por que as crianças precisam aprender a nadar nessa idade.

A principal situação, eu acredito que para a maioria dos pais é a situação de morrer afogado, né? A criança que não sabe nadar, principalmente durante a cheia, a água fica muito

8 Tefé é uma das cidades de médio porte mais próximas da comunidade estudada. Fica no interior do estado do Amazonas, com 62662 habitantes, de acordo com o Instituto Brasileiro de Geografia e Estatística (2010) e localizada a 545 quilômetros da capital Manaus. 
perto, e de repente a gente se descuida, a criança pode cair na água. Então, quando ele já fica numa idade que a gente já pode ensinar ele nadar, a preocupação já tem que ser ensinar. (N., entrevista)

Casos de afogamento e mortes são lembrados nas conversas que envolvem as águas, cujas narrativas estão muito marcadas nas memórias dos moradores: uma criança (de 5 anos) que morreu afogada e foi encontrada porque continuava com seu carrinho de plástico nas mãos, outra (de 4 anos) que nunca foi encontrada, mas todos têm certeza que caiu na água, pois encontraram só as sandálias na estrutura de onde possivelmente tenha caído, e uma terceira (também com 4 anos) caiu na água e foi encontrada apenas depois de vários dias. Todas essas crianças que morreram afogadas não sabiam nadar. Essas narrativas foram frequentemente recontadas nas rodas de conversas, durante o período do campo, pois nesse período um rapaz que ia participar de campeonato de futebol havia morrido depois de cair na água embriagado. Assim, os cuidados com as águas são sempre destacados nas narrativas dos moradores, como expressa um dos interlocutores, «a água é vida, mas é uma das nossas maiores inimigas».

Quando se aprende a nadar algumas limitações já não são mais postas às crianças - elas podem pegar uma canoa sozinhas ou ir com outras pessoas, que não sejam os pais, para outras comunidades, para as roças ou lagos. Portanto, aprender a nadar também amplia as possibilidades das crianças participarem também dos espaços produtivos. Saber nadar é uma condição que legitima a criança a ter mais «liberdade» ou autonomia para circular em diversos espaços, sem o olhar «direcionado» dos adultos. Isso não significa que as crianças não tenham liberdade antes disso, elas estão em constante movimento, porém junto com pessoas mais velhas vigiando ou sendo cuidadas, como nas imagens a seguir. Tal liberdade também não é ausência de regra, o sistema hierárquico de organização familiar permanece, e as crianças ainda obedecem e são vigiadas pelos pais constantemente, porém a forma de cuidado muda. 
Figura 3

Pai trabalhando e as crianças brincando na água

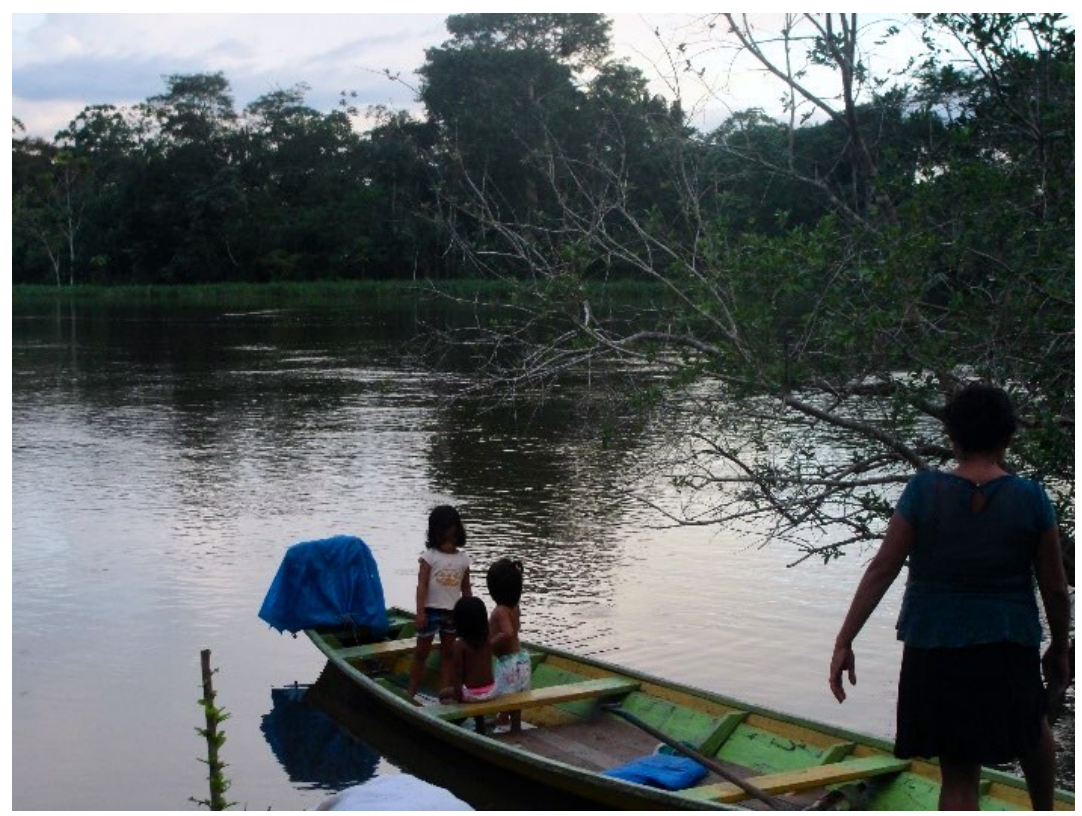

Nota. @ 2019 R. Oliveira.

Figura 4

Crianças brincando na canoa e a mãe de uma delas acompanhando

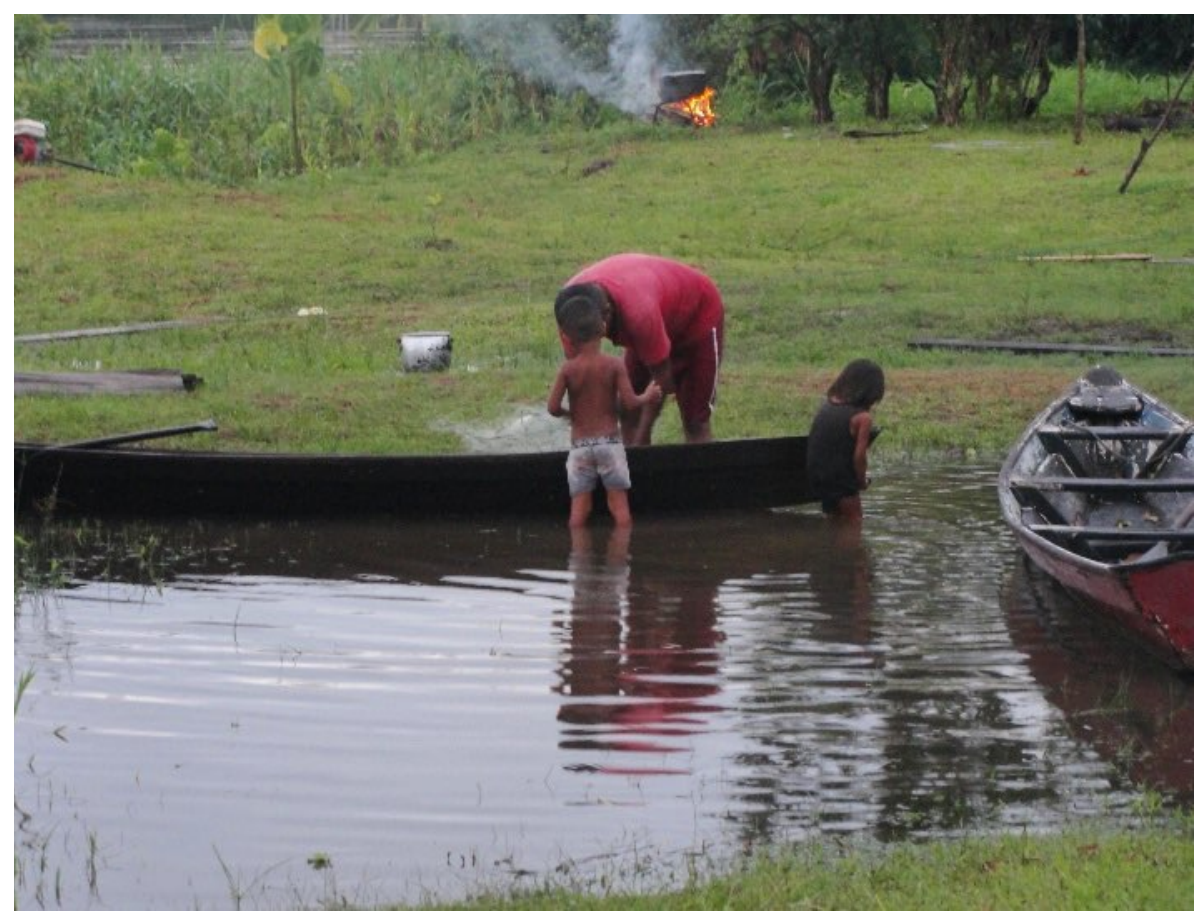

Nota. @ 2019 R. Oliveira. 
As crianças apresentadas nas imagens ainda não sabem nadar, estão em processo inicial de aprendizagem, na interação com os mais velhos, até obterem autonomia para circular de forma mais livre e autônoma. As fotografias mostram as crianças em paisagens acompanhadas de pessoas de diferentes idades e com múltiplos objetos: canoas, remos, motores. Todos objetos e pessoas inseridos em ambientes aquáticos, uma inserção prática com o ambiente de aprendizagem.

\section{Técnicas de corpo e interações de aprendizagem}

O corpo, como o primeiro e o mais natural instrumento técnico (Mauss, 2003) é constantemente treinado nos passos iniciais da aprendizagem do nado. O treinamento envolve técnicas de bater os braços e as pernas na água, além de, durante o mergulho, ter cuidado com os olhos, o nariz e a boca para que não entre água. O aprendiz tem que ficar atento às questões específicas do corpo, com habilidades essenciais para a eficácia da aprendizagem proporcionando também bem-estar ao próprio corpo. Ouve-se muitas vezes que durante a aprendizagem não se deve agoniar para não se afogar, ou seja, deve-se aprender também a controlar a ansiedade durante essa fase.

Seguramente, no contexto observado, a aprendizagem do nado não é um processo linear, nem mesmo formalizado, pois essa aprendizagem é parte da vida. Logo as crianças estão em constante processo de teste não direcionado, ou seja, existem diversas oportunidades para que os corpos sejam habituados a estarem dentro da água. Quando estão sozinhas (sendo monitoradas de longe) na água, as crianças geralmente não mergulham a cabeça, pois o mergulho é habilidade que se desenvolve mais tarde. Logo, ficam correndo, sentadas, batendo as pernas, brincando entre elas, como mostra a imagem a seguir.

Em uma visualização por etapas dessa aprendizagem, é possível identificar primeiro que, as crianças brincam na água, nas áreas baixas, onde correm, pulam e em alguns momentos treinam batidas das pernas na água, com o apoio das duas mãos na terra e não mergulham. Em uma segunda etapa podemos considerar que há interação com outras crianças mais velhas e adolescentes que levam as crianças que não sabem nadar para lugares de maior profundidade e treinam as crianças a baterem pernas e braços, bem como a mergulhar (submergem a criança na água, porém pedem para que com uma das mãos tapem o nariz). Outras vezes seguram as crianças pela barriga e girando pedem para que batam os braços e as pernas. Na última etapa as crianças são desafiadas a nadarem em lugares mais fundos, porém com alguém que saiba nadar por perto. Elas batem pernas, braços e mergulham. Nessas ocasiões pode ocorrer da criança se afogar. 
Figura 5

Crianças brincando na canoa e a mãe de uma delas acompanhando

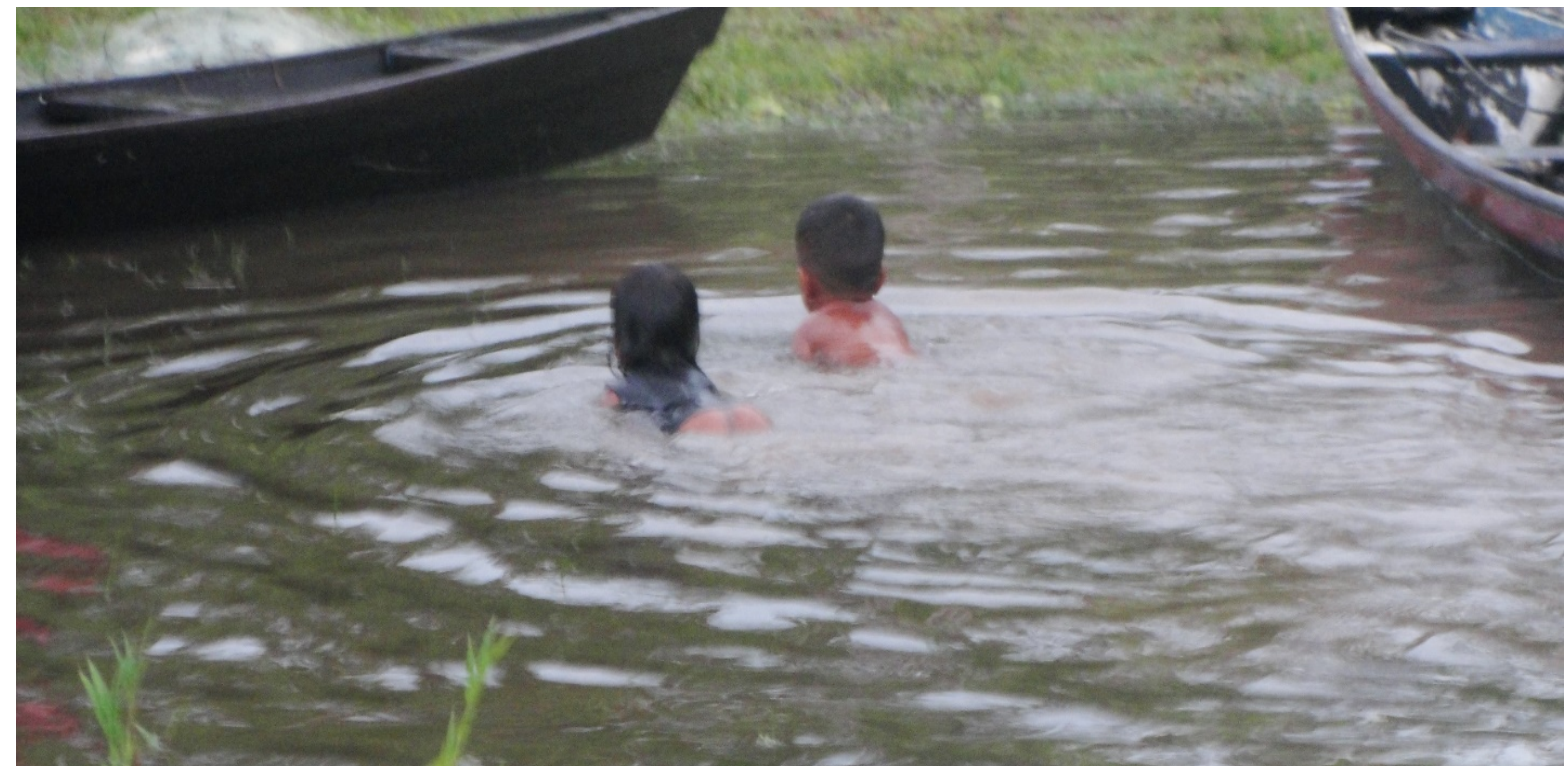

Nota. @ 2019 R. Oliveira

$\mathrm{Na}$ tarde de domingo fui convidado por F. para «pular n’água», sempre que tinha oportunidade fazia isso, nesse dia não foi diferente. À medida que fomos nos aproximando do local, várias crianças também se aproximaram com objetivo de «pular n'água». Todas as brincadeiras como «pira»e «briga de galo» aconteceram. Porém, destaco nesse dia o fato de uma criança que não sabia nadar ser estimulada de forma prática. A criança de quatro anos tinha que se movimentar, em uma distância de 2.5 metros, entre dois adolescentes, um a soltava e ela tinha que nadar até o outro que a segurava, quando se aproximava. Ao ritmo de brincadeira os adolescentes estimulavam na criança a prática do nado. (Diário de campo, maio de 2017)

A educação da atenção (Ingold, 2010) necessita do envolvimento prático dos indivíduos com o ambiente. Nesse ambiente ocorrem ações diversas de interação, que levam a aprendizagem. Para que haja tal interação é necessário existir uma comunidade de prática, pois «los aprendices participan inevitablemente en comunidades de práctica y que el dominio del conocimiento y la destreza les exige a los novatos acercarse a la participación plena en las prácticas socioculturales de una comunidad» (Lave \& Wenger, 1991, p. 1).

As pessoas na comunidade estudada têm em suas memórias os marcadores temporais e espaciais, períodos e locais em que aprenderam a nadar, geralmente em períodos de cheia. Os pais lembram-se dos filhos e sempre falam «fulano aprendeu a nadar na 
cheia do ano passado», ou os próprios aprendizes com: «eu aprendi ano passado, com X anos, em X lugar» e a partir disso descrevem como as coisas ocorreram, quais foram os fatos mais marcantes, de medo, euforia, afogamento, como no caso a seguir:

J. aprendeu a nadar em meados de 2007 no igarapé na própria comunidade. Segundo ela teve auxílio do tio, que a estimulou a atravessar o igarapé que estava cheio e com correnteza da água estava intensa. Narra que sentia muito medo, mas o tio a assegurava estaria ali para socorrer, caso precisasse. O desafio dela seria atravessar sozinha o igarapé, que tinha uma largura de mais ou menos 5 metros. Relata que sentiu medo, chegou a falar várias vezes que não iria, porém chegou um momento que «a coragem chegou» e se «jogou n'agua», apavorada não conseguia fechar os olhos, mas impulsionava braços e pernas para atravessar o igarapé. J. nessa primeira tentativa se «afogou um pouco» e se agarrou no primeiro tronco de árvore que encontrou e o tio de imediato se aproximou para ajudá-la. Foi o momento mais difícil, segundo ela, porém fez isso mais quatro vezes e foi o suficiente para perder o medo e aprender a nadar. (Diário de campo, maio de 2017)

$\mathrm{Na}$ interação com as pessoas que já sabem nadar, o processo da aprendizagem é diferente, pois pode-se pensar em uma intenção, ou técnica de educação do mergulho (Mauss, 2003) e consequentemente do nado. As crianças aprendizes são estimuladas ou orientadas a fazer gestos e esforços de técnicas corporais que fazem parte de como nadar naquela cultura. Mauss (2003) mostra como essas técnicas podem ser dinâmicas ao destacar que

outrora nos ensinavam a mergulhar depois de ter aprendido a nadar. E, quando nos ensinavam a mergulhar, nos diziam para fechar os olhos e abri-los dentro d'água. Hoje a técnica é inversa. Começa-se toda a aprendizagem habituando a criança a ficar dentro d'água de olhos abertos. Assim, mesmo que nadem, as crianças são treinadas sobretudo a controlar reflexos perigosos, mas instintivos dos olhos, são antes de tudo familiarizadas com a água, para inibir medos, criar segurança, selecionar paradas e movimentos. (p. 40o)

Nesse contexto, o autor demonstra as mudanças de técnicas de educação para se nadar, que mudam com o tempo. Na comunidade observada, as crianças são orientadas por outras crianças ou jovens que já sabem nadar, a tapar o nariz com a mão, e cerrar os olhos ao mergulhar, embora geralmente não consigam fechar devido à insegurança e o medo.

Outra forma de aprendizagem do nado, relembrado na memória de algumas pessoas, são os desafios impostos por adultos, em que as crianças que não sabem nadar são atiradas em lugares fundos, para que se debatam até chegar a um local onde possam se firmar. Esse desafio pode ser colocado de forma simples, que a criança atravesse um córrego 
raso, ou mais complexo, quando crianças são literalmente atiradas para um lugar fundo, por várias vezes, até que cheguem à margem do rio, como será possível observar na narrativa abaixo. Estas histórias são contadas entres risadas, nas rodas de conversas, porém muitas mães (geralmente são os pais que fazem tal prática) ressaltam seu sofrimento ao ver os filhos nesse tipo de situação, bem como das lembranças do choro das crianças, porém sempre destacam «que é melhor do que morrer afogado». Uma das nossas interlocutoras narrou como o seu filho C. aprendeu a nadar:

Ele tinha 5 anos e ainda não sabia nadar, o pai dele tinha medo e eu também, porque é perigoso morrer afogado. $\mathrm{O}$ pai dele pegou ele e não teve muita pena, não: jogava ele para o meio do rio. Eu estava vendo, ele jogava e o C. boiava assustado, com o olho regalado, com medo e queria chorar, mas o meu marido continuava, fez isso umas três vezes, até eu já queria chorar vendo isso daqui, mas era para o bem dele. (Entrevista A., maio de 2017)

As técnicas de nado, dos que já sabem nadar, são com batidas leves e puxadas para frente, com os braços, há também batidas com as pernas, porém as pernas não emergem da água, diferente dos braços que são postos para fora da água, inclinados para frente $\mathrm{e}$ impulsionados a puxar a água com as palmas das mãos. A cabeça também não é totalmente imersa na água, ora o rosto é imerso, ora é posto para fora da água e inclinado para os lados. Apesar de não ser uma regra geral, as meninas não nadam da mesma forma que os meninos, diferente dos meninos elas ficam a maior parte do tempo com a cabeça para fora da água e não batem o braço da mesma forma, não fazem a inclinação para frente e batem os braços imersos. Mesmo com essa diferença de técnicas entre os gêneros, meninas e meninos não nadam separados, os mesmos espaços são compartilhados por todos.

Aprender a nadar na primeira infância é condição para que as crianças ribeirinhas estejam aptas a participar de outros patamares de aprendizagem em outros espaços, como o espaço da aprendizagem na pesca navegando na popa das canoas dos pescadores da família.

Entendemos que aprender é parte fundamental para a produção e reprodução dos modos de viver na Amazônia. Mas partimos da abordagem da prática que explica a aprendizagem como derivada da participação dos sujeitos em uma prática social. Para Sautchuk (2015) aprender é um conceito complexo na antropologia, pois as denominações de transmissão e reprodução não são suficientes para explicar os processos de aprendizagem. Desse ponto de vista, concordamos com a afirmativa que «el aprendizaje es una dimensión integral e inseparable de la práctica social» (Lave \& Wenger, 1991, p. 2). Aprender é um processo diverso, que envolve a corporalidade e as gesticulações, e que 
varia de acordo com a sociedade e com o tempo Mauss (2003). Ao analisar as considerações de Ingold sobre aprendizado, Sautchuk (2007) afirma que, o aprendizado não ocorre por transmissão, mas pelo envolvimento em um contexto particular. O engajamento nas práticas também é reconhecido por Lave e Wenger (1991) como fundamental nas iniciações de aprendizagem. A prática ou o envolvimento com o ambiente é o que possibilita o que Ingold (2010) entende como educação da atenção —um processo de interação no ambiente entre aprendiz e veteranos da prática.

Figura 6

Meninos nadando, em frente à comunidade, com objetivo de chegar ao local onde estão outras crianças, o local de encontro nas águas

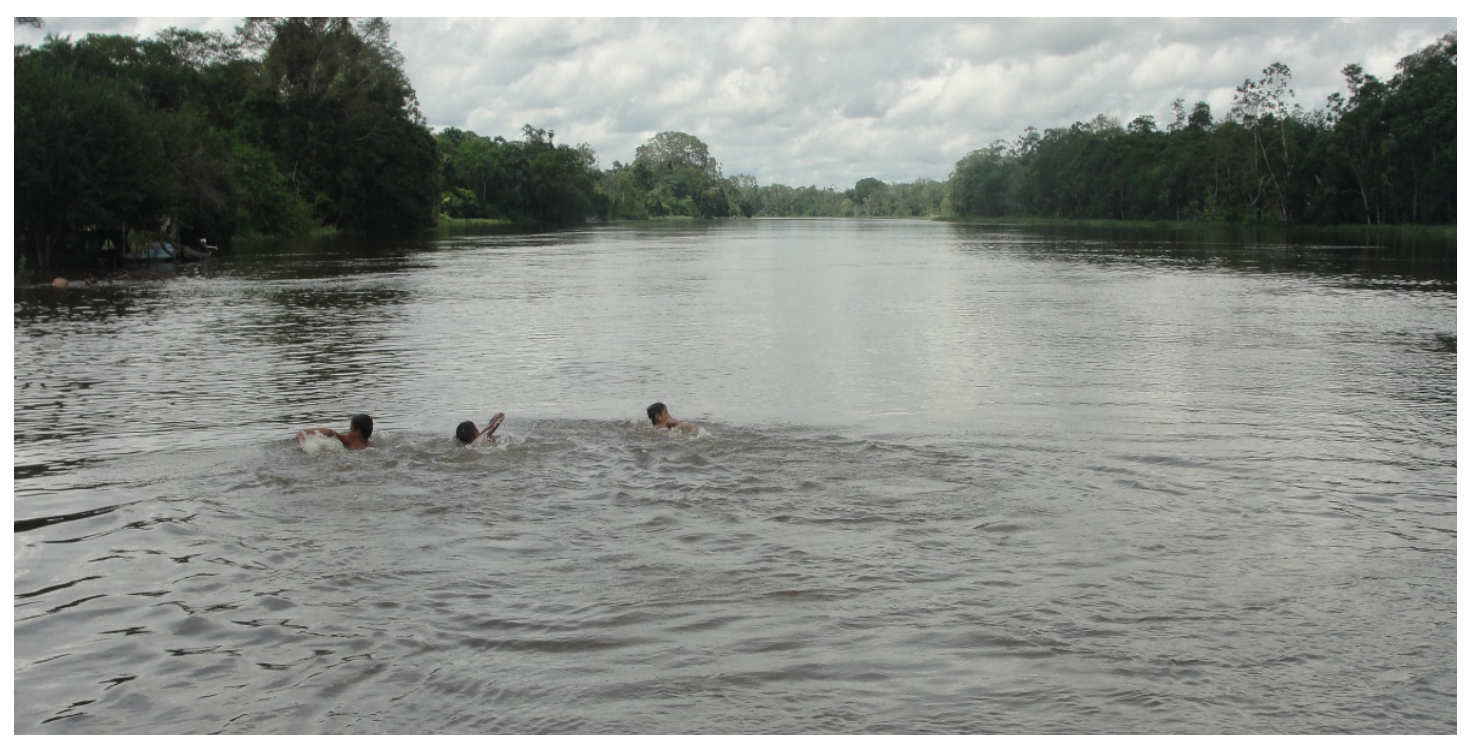

Nota. (C) 2019 R. Oliveira.

Saber nadar tem ligação com a ocupação e uso do espaço, pois podemos considerar que é a partir da ocupação e das relações estabelecidas por meio das condições ambientais e sazonais, que os indivíduos desenvolvem habilidades individuais, porém integradas ao contexto cultural, em um processo de circulação de saberes entre as diferentes gerações e em conexões com crenças, objetos e pessoas.

Para essa aprendizagem, como vimos, há um treinamento do corpo, com a ida das próprias crianças em direção as águas ou com o auxílio de outras pessoas (outras crianças, jovens e adolescentes), que não só orientam posições e gestos, mas servem de modelos para aprendizagem, como observa (Mauss, 2003, p. 405) «a criança imita atos bem sucedidos que ela viu serem efetuados por pessoas nas quais confia e que têm autoridade sobre ela». 
Portanto, a aprendizagem precisa de um contexto específico (os espaços mais rasos na época das cheias) e um contexto de interação social —neste caso entre jovens e crianças de diversas idades. A aprendizagem é participação no mundo social e nadar é uma habilidade que confere à criança outra posição no contexto social da comunidade. Assim afirma Jean Lave, quando fala que as capacidades não se movem para dentro da cabeça das pessoas, mas as pessoas se movem em comunidades de práticas (Lave \& Wenger, 1991).

Dentro da comunidade podemos considerar um patamar social, pois para que a criança tenha liberdade para circular sem ser «vigiada», precisa ter o domínio das técnicas do nado, portanto passam por um processo de legitimação, mudam de status na comunidade e se constituem como agentes que dominam aspectos centrais de uso daquele espaço. Para Lave e Wenger (1991, p. 5 ) «la forma que adquiere la legitimidad de participación es una característica que define las formas de pertenecer, y por lo tanto, no es sólo una condición fundamental para el aprendizaje, sino un elemento constitutivo de su contenido».

Pertencer ao grupo social implica na aprendizagem de diversas habilidades, como na pesca por exemplo, que segue os mesmos parâmetros do nado, nessa comunidade de prática. A pesca é uma atividade que envolve a aprendizagem prática, com envolvimento entre gerações e as águas. Os meninos são iniciados ainda muito jovens, começam cedo a frequentar as popas das canoas dos pais ou de outros parentes adultos ou jovens. Mas, para que possam acompanhar esses adultos durante a atividade de pesca, é preciso que esses meninos saibam nadar.

Quando os homens adultos não têm outro adulto ou jovem para acompanhá-los são os meninos, seus filhos, sobrinhos ou netos que os acompanham, porém apenas em atividades que não demandam muito tempo, nem esforço dos meninos (de 6 a 8 anos em geral). No discurso dos adultos, os meninos contribuem com sua presença para a segurança de ter alguém por perto. Nessa fase os meninos observam as atividades, os gestos, os modos dos adultos pescadores e são integrados na prática por meio da execução dessas pequenas tarefas, como tirar água da canoa e carregar algum objeto. Porém, os meninos mais velhos (entre o9 e 12 anos) são envolvidos nas atividades de forma mais direta, nos lances com captura de peixes que sobem no rio, nas armações e vigílias de malhadeiras (redes de pesca). Muitas vezes, esses meninos mais velhos são os únicos responsáveis pela pesca do peixe consumido pela família.

Dois casos foram narrados pelos pais, de filhos os acompanhando nas atividades de pesca. O pescador C. nos contou sobre o seu filho de 8 anos que sempre o acompanha, mas disse também que a mãe do menino não gosta que ele acompanhe o pai nas pescarias, pois 
tem medo que o jacaré alague a canoa, ou qualquer outra coisa ocorra com a criança. Porém, mesmo assim o filho acompanha o pai sempre. O pescador nos descreveu que quando sai para pescar muito cedo, de madrugada, ele coloca uma tábua na canoa para que o filho possa dormir, segundo ele «o bicho dorme que só».

O filho do pescador $\mathrm{S}$. de seis anos também acompanha o pai. Ele explicou que o filho sempre vai, até mesmo para o lago, pois «é muito ruim o cara andar só, tem que ter alguém para falar». Narrou também que na primeira vez «o menino tinha muito medo, com tudo se assustava, até com aruanã boiando», mas que hoje já está bem tranquilo. Segundo o pescador, o ruim de andar com o filho é que este faz muitas perguntas: «tudo quer saber, que até atrapalha o cara». Para S. seu filho é um menino que gosta de ir nessas pescarias, o que indica que vai gostar muito de pescar.

Os lances de rede de pesca nos rios e armações de malhadeira nas margens são momentos práticos de iniciação dos meninos na pesca. Porém não são momentos específ1cos para os meninos entrarem em uma canoa e participarem de alguma atividade na comunidade, pelo contrário eles estão desde muito cedo na prática junto com os pais. Durante a observação sobre a pesca é possível visualizar que a inserção nessa prática social acontece quando colocam os meninos na popa da canoa para ir junto «olhar a malhadeira», dessa forma vão participando de forma periférica da atividade. Nos lances os meninos vão ajudando, remando ou mesmo soltando as malhadeiras, junto com os pais ou outros jovens. Quando já sabem nadar bem, chegam a ir sozinhos para fazer essa vigília da malhadeira que ocorre durante o dia ou podem mesmo liderar um lance.

A pesca é uma atividade praticada em geral pelos homens na comunidade. Os meninos são inseridos na aprendizagem da atividade ainda muito jovens, nas participações indiretas, nos acompanhamentos, nas ajudas aos mais velhos, gerando assim um processo de aprendizagem e legitimidade, que garantirá a sua autonomia para pegar a proa da sua própria canoa e pescar sozinho, que no geral vai acontecer por volta dos 15 anos de idade. Essa questão também foi identificada por Sautchuk (2015):

Os laguistas estão desde muito novos na canoa de um tutor masculino (pai, tio ou irmão), onde são englobados pelo sistema de percepção e de ação do arpoador mais experiente, que se dedica a sua aprendizagem. Ele cresce com um arpão à mão, desenvolvendo-se conjuntamente à arma, e sai desse sistema para sua própria canoa quando reúne os atributos necessários. (p. 504) 
Perpassa por essa questão a interação em uma comunidade de prática, a legitimação, as técnicas de corpo, bem como patamares de aprendizado. Até que sejam pescadores independentes, os meninos passam por diversas etapas da aprendizagem de forma direta e indireta, o que possibilita a experiência e a construção de habilidades individuais. O nado é uma habilidade essencial para a formação da pessoa na comunidade. Só depois que os meninos aprendem a nadar estão aptos a acompanhar os pais, avós, tios ou outros adultos nas suas pescarias, adentrando assim no mundo do trabalho masculino, que vai permitir, por sua vez, que se torne um pescador.

\section{Discussão dos resultados}

Para aprender a nadar as crianças são direcionadas às experiências práticas. $\mathrm{Na}$ interação com seus pares, ao mesmo tempo que se divertem, se preparam para enfrentar outras etapas da vida, ou seja, é uma aprendizagem também para a vida adulta, conforme constatam de Cardoso e Souza (2011) ao abordarem a temática da infância na Amazônia. Os resultados indicam que aprender a nadar representa não só garantia da sobrevivência em um lugar «cercado» por águas, a mobilidade dos indivíduos no território, mas também a possibilidade de atuação nas atividades produtivas, como a possibilidade de formação do pescador como sujeito, que o torna apto e disposto a ser e agir como pescador no ambiente. Tal aprendizagem ocorre no próprio contexto físico da comunidade, porém tem grande influência das dinâmicas da sazonalidade com a proximidade das águas na cheia, nesse período as crianças aprendizes têm mais possibilidade de interação com os ambientes de aprendizagem do nado.

O nado significa também um passo no percurso de aprendizagem de outras atividades, como a caça, pesca e agricultura. Trabalhos que discutem de forma direta e indireta a aprendizagem entre as crianças na Amazônia (Andrade \& Pacheco, 2016; Cardoso \& Souza, 2011; Medaets, 2013, 2018; Morelli, 2017; Sautchuk, 2007, 2015; Sousa \& Montardo, 2014) são destacados principalmente o envolvimento delas nas atividades de produção, seja na aprendizagem, na execução ou as duas juntas, na construção da identidade. Para Cardoso e Souza (2011, p. 165) «a inserção das crianças no trabalho funciona como uma estratégia de socialização e de auto reprodução, indispensável para o fortalecimento dos laços familiares, para a construção da distinção entre a fase adulta». Medaets (2018) afırma que a inserção das crianças, em atividades produtivas as prepara para a vida na comunidade. Apesar de aprender a nadar parecer ser uma atividade trivial, identifica- 
mos que o mau desempenho na prática pode afetar a própria constituição do sujeito ribeirinho, que não acontece de forma simples, nem aleatória, mas é envolta no complexo sistema da cultura local, envolvendo as práticas, as experiências, o lazer, o trabalho.

Identificamos também outras possibilidades de pesquisa e análise para a temática, como por exemplo, a variação da técnica por sexo e por idade. Porém, a nossa pesquisa em campo foi limitada para uma descrição mais detalhada dessas questões. Embora não haja divisão entre espaços ou brincadeiras entre meninas e meninos das atividades nas águas, identificamos diferenças em alguns movimentos específicos dos membros ao praticarem o nado. Outro limite da pesquisa foi em identificar uma possível mudança na técnica do nado e na educação para o nado (Mauss, 2003) entre diferentes gerações. Também há possibilidade para pesquisa a comparação entre as técnicas em ambientes de várzea e terra firme.

\section{Considerações finais}

As crianças ribeirinhas vivem em processos dinâmicos de aprendizagens, com grande imersão prática, desde muito cedo estão na interação comunitária e familiar de produção de alimentos, atividades de lazer e outros eventos integrados ao modo de vida. Dentro dessa dinâmica seus corpos são habilitados por meio da inserção em uma comunidade de prática, na pesca, na agricultura e no nado, atividades que estão diretamente ligadas ao saber ocupar o espaço. A aprendizagem não acontece da mesma forma: cada indivíduo tem seu ritmo integrado aos aspectos de sazonalidade e interação entre pessoas, que envolvem esforços diferenciados.

A água é também considerada pelos moradores como perigosa, por isso também as crianças são incentivadas a desenvolver habilidades na água, que possibilita a circulação das crianças de forma autônoma pelo espaço da comunidade, bem como além dele. Em uma comunidade de práticas e na interação com o ambiente, as crianças constroem as técnicas que habilitam seus corpos para aprendizagem. Para isso contam com os espaços escolhidos, que existem a partir da subida da água. A aprendizagem acontece entre as brincadeiras e as interações com outras crianças, adolescentes, jovens e adultos que já sabem nadar. É possível visualizar que as crianças passam por diferentes patamares até que sejam reconhecidas pelos pares, como alguém que sabe nadar, bem como se autolegitimarem internamente com segurança para explorar as águas, com as técnicas do nado. 
Dentre as técnicas estimuladas por adultos estão as que forçam as crianças a aprenderem em um só evento, jogando-as à água, para que aprendam de forma imediata. Essa atitude que parece radical, diante do risco de um afogamento, possibilita que a criança adentre o universo dos adultos e nas dinâmicas da comunidade de forma mais efetiva. A criança adentra o próximo espaço de aprendizagem e de formação de sua pessoa, pois passa a se movimentar em uma nova comunidade de práticas. Isso porque, como nos ensinam Lave e Wenger (1991) comunidades de prática estão engajadas no processo gerador de seu próprio futuro.

Em conclusão podemos afirmar que aprendizagem do nado é uma atividade com alta relevância para o modo de vida ribeirinho. A aprendizagem para a criança é fundamental para sua sobrevivência, para além da infância. Assim, a análise social desse processo traz possibilidades de um entendimento da infância ribeirinha nessa região, o que amplia as discussões no âmbito das ciências sociais sobre o ser criança na Amazônia rural.

\section{Agradecimento}

Agradecemos especialmente a todos os moradores e moradoras da comunidade São Paulo, pela disponibilidade de realização da pesquisa. Às instituições apoiaram financeiramente o projeto: Fundação Gordon and Betty Moore (Moore) e Conselho Nacional de Desenvolvimento Científico e Tecnológico (CNPq). À instituição que viabilizou a bolsa de pesquisa, que gerou os resultados apresentados: Instituto de Desenvolvimento Sustentável Mamiraua (IDSM).

\section{Referências}

Alencar, E. F. (2007). Estudo da ocupação humana e mobilidade geográfica de comunidades rurais da Reserva de Desenvolvimento Sustentável Amanã-RDSA. IDSM.

Alencar, E. F. (2009). O tempo dos patrões «brabos»: fragmentos da história da ocupação humana da reserva de desenvolvimento sustentável Amanã-AM. Amazônica, Revista de antropologia, 1, 178-199. https://doi.org/10.18542/amazonica.v111.148

Alencar, E. F. (2010) Dinâmica territorial e mobilidade geográfica no processo de ocupação humana da Reserva de Desenvolvimento Sustentável Amanã-AM. Uakari, 6, 39-58. 
Andrade, S. S., \& Pacheco, T. do S. C. (2016). Infâncias e crianças ribeirinhas da Amazônia marajoara: linguagens e práticas culturais. Revista @rquivo Brasileiro de Educação, 4(9), 104-116. https://doi.org/10.5752/P.2318-7344.2016v4n9p104

Ayres, J. M. (2006). As matas de várzea do Mamirauá. Sociedade Civil Mamirauá.

Cardoso, L. F. C., \& Souza, J. L. C. de. (2011). Viver, aprender e trabalhar: habitus e socialização de crianças em uma comunidade de pescadores da Amazônia. Boletim do Museu Paraense. Emílio Goeldi, 6(1), 165-177. http://dx.doi.org/10.1590/S1981-81222011000100010 Cohn, C. (2013). Concepções de infância e infâncias: um estado da arte da antropologia da criança no Brasil. Civitas, Revista de Ciências Sociais, 13(2), 221-244. http://dx.doi.org/ 10.15448/1984-7289.2013.2.15478

Cunha, L. de L. (2013). Os clássicos da «literatura» sociológica infantil: as crianças e a infância de acordo com Marx, Weber, Durkheim e Mauss. Plural, 20(1), 83-97. https://doi.org/10.11606/issn.2176-8099.pcso.2013.74416

Cunha, L. H. H. (200o). Igreja e manejo comunitário de lagos na várzea amazônica [Apresentação]. X Congresso Mundial de Sociologia Rural, Rio de Janeiro, Brasil.

Ingold, T. (2010). Da transmissão de representações à educação da atenção. Educação, 33, 6-25. Instituto Brasileiro de Geografia e Estatística. (2010). Glossário dos termos genéricos dos nomes geográficos utilizados no mapeamento sistemático do Brasil. Ministério do Planejamento, Orçamento e Gestão.

Lave, J., \& Wenger, E. (1991). Situated learning: Legitimate peripheral participation. Cambridge University Press.

Lima, D. de M. (2004). Ribeirinhos, pescadores e a construção da sustentabilidade nas várzeas dos rios Amazonas e Solimões. Boletim Rede Amazônia, 3, 57-66.

Lima, D. de M., \& Peralta, N. (2016). Programas de transferência de renda em duas Unidades de Conservação na Amazônia brasileira e Sustentabilidade. Novos Cadernos Naea, 19(2), 43-67. http://dx.doi.org/10.5801/ncn.v19i2.2379

Little, P. (2004). Territórios Sociais e Povos Tradicionais no Brasil: Por uma Antropologia da Territorialidade. Anuário Antropológico, 28(1), 251-29o.

Loureiro, J. de J. P. (2015). Cultura amazônica: uma poética do imaginário. Valer.

Mauss, M. (2003). Sociologia e antropologia. Cosac Naify.

Medaets, C. (2013). «A prometida»: normas educativas e práticas disciplinares em comunidades ribeirinhas da região do Tapajós, estado do Pará. Civitas, 13(2), e1-e14. https://doi.org/10.15448/1984-7289.2013.2.16474

Medaets, C. (2018). Crianças na economia familiar do Baixo-Tapajós (pará) ajudar, aprender, «se acostumar». Civitas, 18(2), 411-430. https://doi.org/10.15448/1984-7289.2018.2.29605 
Morelli, C. (2017). The river echoes with laughter: A child-centred analysis of social change in Amazonia. Journal of the Royal Anthropological Institute, 23(1), 137-154. https://doi.org/10.1111/1467-9655.12548

Neves, D. P. (2006). O MEB-Movimento de Educação de Base, a organização comunitária e a preservação ambiental [Apresentação]. VII Congresso Latinoamericano de Sociologia Rural, Quito, Ecuador.

Ramalho, E. E., Macedo, J., Vieira, T. M., Valsecchi, J., Calvimontes, J., Marmontel, M, \& Queiroz, H. L. (2009). Ciclo hidrológico nos ambientes de várzea da Reserva de Desenvolvimento Sustentável Mamirauá-médio rio Solimões, período de 1990 a 2008. Uakari, 5, 61-87.

Reis, M. (2005). Arengas e picicas: reações populares à reserva de desenvolvimento sustentável mamirauá no estado do Amazonas. Sociedade Civil Mamirauá.

Sautchuk, C. E. (2007). O arpão e o anzol: técnica e pessoa no estuário do Amazonas [Tese Doutorado não publicada]. Universidade de Brasília.

Sautchuk, C. E. (2015). Aprendizagem como gênese: prática, skill e individuação. Horizontes Antropológicos, 21(44), 109-139. https://doi.org/10.159o/s0104-71832015000200006

Silva, R. C. da. (2013). Circulando com os meninos: participação e aprendizado da criança Xakriabá na exploração do território e da atividade da caça. Tellus, 13, 35-55.

Silva, R. C. da., \& Gomes, A. M. R. (2015). Learning, body and territory among indigenous Xakriabá boys. Horizontes Antropológicos, 21(44), 173-200. https://doi.org/10.159o/ s0104-71832015000200008

Sousa, M. de J. S. (2017). Teçumes e Teçumeiras: etnografia da construção de identidade política das artesãs da Reserva de Desenvolvimento Sustentável Amanã-AM [Tese Doutorado não publicada]. Universidade Federal do Amazonas.

Sousa, M. de J. S., \& Montardo, D. L. O. (2014). Performance Corporal no processo de ensino-aprendizagem entre os artesãos da Reserva de Desenvolvimento Sustentável Amanã, Médio Solimões, Amazonas. Amazonica: Revista de Antropologia, 6(1), 28-49. https://doi.org/10.18542/amazonica.v6i1.1747

Tocantins, L. (1973). O rio comanda a vida: uma interpretação da Amazônia. Biblioteca do Exército.

Witkoski, A. C. (2010). Terras, florestas e águas de trabalho: os camponeses amazônicos e formas de uso de seus recursos naturais. Annablume. 